\title{
Personhood and (Rectification) Justice in African Thought
}

\section{Motsamai Molefe}

To cite this article: Motsamai Molefe (2018): Personhood and (Rectification) Justice in African Thought, Politikon, DOI: 10.1080/02589346.2018.1435020

To link to this article: https://doi.org/10.1080/02589346.2018.1435020

\section{曲 Published online: 04 Mar 2018.}

Submit your article to this journal ๘

Q View related articles $\widetilde{ }$

View Crossmark data $\widetilde{ }$ 


\title{
Personhood and (Rectification) Justice in African Thought
}

\author{
Motsamai Molefe \\ Department of Philosophy, University of the Witwatersrand, Johannesburg, South Africa
}

\begin{abstract}
This article invokes the idea of personhood (which it takes to be at the heart of Afrocommunitarian morality) to give an account of corrective/rectification justice. The idea of rectification justice by Robert Nozick is used heuristically to reveal the moral-theoretical resources availed by the idea of personhood to think about historical injustices and what would constitute a meaningful remedy for them. This notion of personhood has three facets: (1) a theory of moral status/dignity, (2) an account of historical conditions and (3) the achievement of moral excellence by the agent (personhood). This article argues that a just society is a function of (1) and (2), and it further argues that the aim of rectification justice is to correct these two facets of a society, which are necessary for (3) to be possible. The aim of correcting history just is to make personhood a possibility for all humanity, particularly of those who were victims of past injustices.
\end{abstract}

\section{Introduction}

How will Afro-communitarianism approach the question of historical injustices occasioned by colonisation and apartheid? In other words, moral-theoretically, what corpus will it provide for thinking about restorative/rectification justice? This article responds to these questions by relying on the normative notion of personhood, which is at the heart of Afro-communitarianism, to account for rectification justice (Gyekye 1997; Wiredu 2008). Moral-theoretically, according to Robert Nozick (2002), justice can be concerned about three distinct moral issues, namely: (1) it can be about permissible initial acquisition of things; (2) a permissible transfer of things between individuals and (3) it can be about correcting historical violations of the two previous forms of justice-rectification justification. ${ }^{1}$

The primary aim of this article is to unpack the three facets that constitute this Afrocommunitarian moral notion of personhood, specifically: (1) the historical facet of this moral notion, which prizes certain historical conditions as crucial for the attainment of personhood; (2) the capacity in virtue of which human beings are intrinsically valuable (the idea of moral status/dignity) and (3) the achievement facet of this notion. My interest in this analysis is to accentuate the facet of historical conditions and the capacity for virtue possessed by human beings as important in both moral-political philosophy, in general, and also, more specifically, for accounting for (rectification) justice. In other words, at the heart of my argument is the idea that to take seriously personhood commits one necessarily (1) to holding the view that particular historical conditions ought to prevail for it to be possible and (2) that one holds a particular conception of human nature that grounds our belief that individuals can attain it (some human capacity

CONTACT Motsamai Molefe Motsamai.molefe@wits.ac.za E University of Kwa-Zulu Natal, New Arts Building, Room 310, Pietermaritzburg, South Africa

(c) 2018 South African Association of Political Studies 
definitive of human dignity), without which a talk of personhood is nothing but a sham. A meaningful talk of personhood requires these two facets as its preconditions.

On the other hand, to talk of rectification justice necessarily implies an evaluation of some historical conditions to be flawed so as to require correction. So, both the notions of personhood and rectification justice are concerned essentially about certain historical conditions as robust features of moral-political thinking. This article, therefore, brings to the fore the backward-looking facet of morality (of personhood) that is generally not emphasised in African ethics. It is this backward-looking facet of personhood that is captured by (1) and (2) that links it to rectification justice - these conditions will specify the moral-political content that should inform the process of remedying the past.

In this article, I do not intend to defend either the plausibility of the moral notion of personhood in its own right or to even suggest it as the only/best way to think about past (injustices) in the African tradition. ${ }^{2}$ I limit myself to two aims. Firstly, my aim is to extend discourse on this crucial notion of personhood to untrodden academic terrains. The literature has generally tended to focus on personhood as a status attained by a human being, i.e. as the moral end or final value (Menkiti 1984; Gyekye 1992, 1997; Wiredu 1992, 2009). It has tended, however, to neglect the facet of human nature (her capacity for virtue) and the historical conditions, which are preconditions that are necessary for the attainment of personhood. It is these facets that constitute the nib and hub of thinking about justice in this moral-political system. Even promising elucidations of this notion by scholars like Kevin Behrens (2013) and Anthony Oyowe (2014) ultimately focus on their analysis of personhood as a moral end. Jason Van Niekerk analysis of this notion as a moral theory is important, but it also focuses on moral ends, the achievement of a particular moral character.

I extend discourse on this notion of personhood by specifically pursuing its implications with regards to the rationale it offers us for thinking about rectification justice. To do so, instead of focusing on personhood as a moral end, I focus on moral-political considerations that are necessary for its possibility. To the best of my knowledge, no one in the literature has invoked this idea of personhood to reflect on what it might offer us in terms of addressing historical injustices, backward-looking duties, or, how it might inform our attempts to account for rectification justice. As such, the aim of this analysis is to extend the discourse of personhood to this neglected facet of political thought in African philosophy.

It is crucial to note that much of the literature in African moral philosophy largely ignores this question of historical injustices in their analysis. Consider, for example, influential texts in African ethics tend to neglect considering how their moral theories might speak to issues of historical injustices. Kwasi Wiredu (1992), one of the most influential African philosophers, writes an excellent article 'Moral Foundations of an African Culture'; but never directly reflects on how it might speak to the problem of historical injustices. For another, consider Augustine Shutte's (2001) ethical elucidation on the moral principle to inform the new South Africa, a country with a terrible history of colonisation and apartheid. This book, make no mistake, offers important insights into moral thinking drawing from ubuntu; but it remains mum on the question of the past and how to approach it.

More recently, Kwame Gyekye (2010) writes an encyclopedic article titled 'African ethics'. This article explores meta-ethical questions, the moral idea of brotherhood, the 
idea of personhood, the duty-based nature of African ethics and many other topics; but it also overlooks the issue of the past as crucial to African ethics. The mere history of African people recommends the past as worth taking seriously morally and politically. This article is an attempt to speak to this lacuna in African moral-political thought in African philosophy, by directly speaking to historical injustices in the light of the ethical notion of personhood. $^{3}$

One major limitation of the analysis to proceed here is that it is cursory at best. The aim is to extend an African moral notion of personhood, so as to explore its possible contribution to the question of historical injustices. The fact that the analysis, here, is cursory, should not be seen as a weakness, but should rather be considered as an invitation for scholars in the tradition of African philosophy to join in and contribute to the moral-political thinking on how to respond to Africa's difficult past.

To make my analytical explorations between personhood and rectification justice, I structure this article as follows. In the first section, I clarify the idea of personhood central to this project. I do so by distinguishing four distinct concepts of personhood in African philosophy. In the light of these conceptual distinctions of the notions of personhood, I suggest a connection between the patient-centred and agent-centred notions in accounting for justice. Secondly, I proceed to unfold the ethical theory usually associated with this idea - a self-realisation moral theory. Finally, I proceed to argue that the two conditions necessary for personhood are at the heart of what is crucial for thinking about rectification justice, namely: (1) what is special about human nature (dignity) and (2) socio-historical conditions (common good).

\section{Concepts of personhood in African philosophy}

I identify at least four distinct concepts of personhood in African philosophy. Talk of personhood could refer to (1) the mere fact that one is a human being (Kaphagawani 2004); (2) it may concern facts about what social and/or psychological factors are crucial for accounting for personal identity (Mbiti 1969; Molefe 2016); (3) it may concern ontomoral feature(s) that distinguish some beings as bearers of moral status (Toscano 2011; Behrens 2013) and (4) it may indicate those moral agents who are leading morally genuine lives (Menkiti 1984; Wiredu 1992, 2004; Gyekye 1992; Ikuenobe 2006).

It is crucial to note that the first two concepts of 'personhood' are metaphysical insofar as they specify certain descriptive facts as the basis for (1) understanding what it means to be human as opposed to being a table or a grain of sand and (2) facts concerning how to account for personal identity. In this kind of analysis, no moral considerations are invoked or even necessary. The last two notions of a person, however, are normative; in other words, they invoke some moral value as a basis for determining the status of personhood.

It is crucial to note, however, that here we are dealing with two distinct normative notions of personhood and these notions play two distinct roles in moral philosophy. One is riveted on an invariable property possessed usually by human beings in virtue of which they deserve our moral regard, which Kevin Behrens refers to as the patientcentred notion of personhood (Metz 2013, 12; Behrens 2013). Thus, to talk of a human being as a possessor of moral status is tantamount to specifying some ontological 
feature in virtue of which she is morally significant and for the very reason of possessing, note, not exercising, this feature, she deserves moral respect (Toscano 2011).

The last notion of personhood invokes respect that accrues variably among moral agents relative to their performance, which Behrens refers to as the agent-centred notion of personhood (Menkiti 2004; Metz 2013). Those who perform well are called 'persons' and those that do not are 'non-persons'. To call a human being a 'person', in this last sense, it is to make a moral judgement that she is leading a true or even a genuinely human life (Wiredu 2009). It is, however, not to deny or to denigrate her humanity qua a biological fact; it is rather to say she is not treating her humanity in the best way possible, morally speaking (Gyekye 1992; Wiredu 2009). Personhood, in this light, is a moral achievement that depends on the agent's performance.

So, the first normative notion of a person speaks of the respect one deserves merely because she possesses the relevant ontological capacity, be it rationality, sentience or capabilities (Darwall 1977); and the other, it refers to respect one earns relative to her performance (Menkiti 2004). ${ }^{4}$ Behrens, in his analysis, notes that the patient-centred notion is prevalent in the Western moral tradition and the agent-centred notion is prevalent in African moral tradition. I depart from the point of view that tethers these two notions to account for justice. ${ }^{5}$ That is, we believe one can achieve personhood (agent-centred) because they possess the capacity for it (patient-centred).

The tethering of these two notions is important because political discussions of justice entirely rely on the patient-centred notion of personhood as it is based on the principles of equal respect that owe to all human beings (Dworkin 1983; Kymlicka 1990). The idea of equality is crucial for justice because it departs from the fact that there is no moral basis to think there are human beings who are more human than others; or, the idea that no one's rights, all things being equal, should count more than those of others (Rachels and Rachels 2015, 13-14). But, here, I think about (rectification) justice in the light of these two notions because they are inherently interlinked to each other (Gyekye 1992). Our moral belief that one can attain personhood relies precisely on what we believe to be at the heart of what makes a human being morally special or superlatively valuable (dignity), which is pivotal for thinking about a just society.

Thus, to take the agent-centred notion of personhood seriously commits one to the view that the ability/capacity for moral agency grounds our conception of moral status. $^{6}$ It is this background theory of moral status qua capacity for moral agency that will be doing much of the job of accounting for justice in this article. So, a talk of personhood as something that is achieved - a variable property that tracks performance depends entirely on (1) the human capacity for moral agency and (2) the social conditions/opportunities that prevail for this attainment to be possible in the first place. The fact that the relationship between (1) and (2) is crucial for explaining how agents come to attain personhood is usually ignored in the literature, though Gyekye (1992, 1997) somewhat approximates it, but never delves into it. I rely on (1) and (2) to build a case for rectification justice in moral-political philosophy.

\section{Personhood and ethical theory}

To say one is a person is one and the same thing as making the moral judgement that they are morally virtuous - a judgement about the quality of their characters. Thus, to talk of 
personhood essentially involves or implies reliance on some system of value (Wiredu 2009; Gyekye 2010). In fact, Gyekye (2010) states: 'The concept of a person in African thought embodies ethical presuppositions'. Wiredu $(2009,15)$ goes even further to comment on the scope of these ethical presuppositions embodied by this idea of personhood, thus:

But such evaluation presupposes a system of values. Since the context of such evaluations is nothing short of the entire sphere of human relations, the system of values presupposed cannot be anything short of an ethic for a whole society or culture.

It is clear from the above that the idea of personhood embodies an ethical system that informs Afro-communitarianism. In other words, at the heart of Afro-communitarian ethical systems is the idea of personhood and, in turn, this idea contains values whose purview extends to the entire sphere of human relations. Or, put differently, if one wants to understand Afro-communitarianism they must appeal to the notion of personhood since it embodies an ethic for a whole (African) society.

For example, Gyekye $(1992,109)$ gives insights into this system of value, thus:

The pursuit or practice of moral virtue is held as intrinsic to the conception of a person. The position here may thus be schematized as: for any $p$, if $p$ is a person, then $p$ in his conduct ought to display norms and ideals of personhood.

It is crucial to note that here Gyekye construes personhood in terms of the pursuit of moral virtue or the very practice of moral virtue. In other words, one who counts as a person is one whose deportment is characterised by certain virtues that reflects the quality of their character. It is therefore not surprising to read Behrens $(2013,111)$ making sense of personhood in terms of 'developing (moral) virtue'. In other words, the idea of personhood posits the achievement of moral virtue as the proper moral goal. Or, as Metz $(2007,331)$ construes, personhood to be tantamount to a self-realisation approach to ethics, wherein the moral agent is expected to achieve a status of moral virtue. The goal is for the moral agent to take that which was biologically given, and convert it to a morally virtuous humanity (Menkiti 1984, 172; Bujo 2001, 88). Augustine Shutte $(2001,14)$ captures this ethic thus:

The moral life is seen as a process of personal growth ... Our deepest moral obligation is to become more fully human. And this means entering more and more deeply into community with others. So although the goal is personal fulfilment, selfishness is excluded.

And, one who has attained this status is described by Desmond Tutu (1999), famous for chairing South African Truth and Reconciliation Commission, in these terms:

When we want to give high praise to someone we say, ' $Y u$, $u$ nobuntu'; 'Hey, so-and-so has ubuntu.' Then you are generous, you are hospitable, you are friendly and caring and compassionate. You share what you have. It is to say, 'My humanity is caught up', is inextricably bound up in yours.

To say some human being has ubuntu is one and the same thing as to say she is a person. A human being that is leading a morally appreciable life is described in terms of having ubuntu (Munyaka and Mothlabi, 2009, 65). It is for this reason that ubuntu is invoked as a response to or as a moral judgement that affirms the quality of one's character or conduct. It is worth noting that one who is a person is characterised by certain virtues like generosity, hospitality, friendliness and compassion, among others. More, the moral 
virtues associated with a person are strictly relational ones; in other words, these are virtues that throw one into relationships with others. Thus, one important facet of the ethics presupposed by the idea of personhood is that the moral agent must develop and manifest certain relational virtues (Metz 2012a). The goal is for the moral agent 'to become a full person, a real self, or a genuine human being' (Metz 2009, 83).

But, there is another facet of this system of values. Above, we have been considering the moral goal posited by this system. Some scholars have brought it to our attention that there is also the side of means - the how part - associated with the idea of personhood (Metz 2013; Tshivhase 2013). Yes, the goal of morality is the attainment of personhood or the perfection of our humanity; but, then, we still have another crucial question to consider: how do we achieve this goal? There is a consensus in the literature that personhood is achieved through entering into relationships with others. For example, Justice Yvonne Mokgoro $(1998,3)$ suggests how personhood is achieved when she comments:

... thus the notion umuntu ngumuntu ngabantu/motho ke motho ka batho ba bangwe, which also implies that during one's life-time, one is constantly challenged by others, practically, to achieve self-fulfilment through a set of collective social ideals.

An influential Kenyan Theologian from, Benezet Bujo (1997, 28), comments:

It is exactly the community which enables the self-realisation of the individual. According to the African representation of values, it is not possible to achieve the ethical ideal individually or as a strictly personal achievement.

Metz $(2012 a, 102)$ also informs us that

... self-realisation is exhausted through other persons', that is, through community alone. It is typical for African theorists to maintain, or at least to suggest, that the only comprehensive respect in which one can live a genuinely human way of life is by communing, or sometimes 'being in harmony', with other people.

From the above, one can only achieve personal-moral perfection by being 'constantly challenged by others' or by being enabled by the community or by 'being in harmony' with others. There is no denial that personal-moral perfection is an individual effort, though this fact is not usually emphasised in the literature, but what comes out clearly is that some form of constant, continual and positive interaction with others is crucial for the attainment of personhood. One such crucial feature of this harmonious engagement with others is the exercise of the other-regarding duties. For example, Wiredu (1992, 200) informs us that one can only become a person relative to the extent that she promotes the welfare of others in the community. David Lutz $(2009,314)$ also informs us that the promotion of the common good - the good of others - entails the promotion of the good of an individual as well, the individual attaining her own personhood.

It is for this reason that Gyekye $(2004,2010)$ has maintained that Afro-communitarianism is best construed as a social ethic characterised essentially by promoting the good of others in the community. Commenting on this ethic, Gyekye (2010) notes: 'African social ethic ... emphasize(s) the importance of the values of mutual helpfulness, collective responsibility, cooperation, interdependence, and reciprocal obligations'. Gyekye further notes: 
Social or community life itself, a robust feature of the African communitarian society, mandates a morality that clearly is weighted on duty to others and to the community; it constitutes the foundation for moral responsibilities and obligations.

So, from the above we see that this moral idea of personhood has two facets. Firstly, the goal of this ethical system is for the agent to realise or become a genuine human being or to be morally virtuous; and, secondly, we get a clear sense that one can realise this status (of personhood) only by entering into relationships with others, wherein she exercises duties to promote their well-being. It is to be kept in mind, though not demonstrated, that the common good is believed to entail the goal of the agent or that the common good does not threaten or undermine the goal of the individual to realise her true humanity (Gyekye 1995, 156; Lutz 2009, 314).

Translated to a principle of right action an Afro-communitarian ethic reads as:

An action is right just insofar as it positively relates to others and thereby realizes oneself; an act is wrong to the extent that it does not perfect one's valuable nature as a social being (Metz 2007, 331).

I proceed in what follows to philosophically articulate how the past matters in the light of an Afro-communitarian ethic of personhood.

\section{Personhood and moral-political philosophy (Justice)}

I have demonstrated that to talk of personhood is to talk of the agent's status of moral excellence. This achievement facet of personhood is obvious and has been elaborated upon extensively in the literature. Here, however, I proceed to focus on two facets of it related to rectification justice that have largely been neglected. Firstly, to take personhood seriously implies that one holds a particular conception about what is special about human nature - a position that has been discussed by Gyekye. Secondly, to take seriously this idea of personhood is tantamount to taking history and socio-historical conditions to be crucial for this kind of a judgement to be meaningful at all.

For one to make the judgement that some agent has achieved personhood, certain socio-historical conditions must hold for the judgement to be valid in the first place. I distinguish between history and historical conditions to bring our attention to the fact that to make the judgement that one is a person implies two sorts of related socio-historical conditions. Firstly, it implies that the making of this judgement requires an assessment of the agent's conduct over time (history); and, secondly, it also implies that the agent is living in a society that avails basic goods she requires to be able to achieve the ideals associated with what is required for her humanity to be perfected. In what follows, I elaborate on these two facets of this notion of personhood with the aim of relating them to rectification justice.

\section{Personhood and history}

I think the intuition that backward-looking considerations should become a crucial facet of a robust moral theory is sustainable. Here, I do not defend why I take this intuition to be plausible. I am content to function on the basis of common sense morality. Two examples will suffice as prima facie evidence for why I take this intuition to be uncontroversial or 
even reasonable. Think about the activity of promise-making. The promiser develops a special relationship with the promisee by merely making the promise. The promisee, merely because of the promise, now has the right to demand that the promiser deliver her promise. The duty of the promiser to the promisee is riveted in the past, the mere fact that he promised. It is precisely because of this past action of making a promise, on the part of the promiser, that the promisee finds herself justified to press demands that one should fulfil their promise. Taking seriously the activity of promise-keeping commits one to taking seriously the intuition that past actions or decisions are an important feature of a robust moral thinking.

For another useful example, think about how to distribute scarce medicine for managing HIV/AIDS. ${ }^{7}$ Suppose we have a case of a trade-off and we can only give the medication to one of the two. And, suppose we have historical facts with regards to how patients got infected with the virus. If the woman was infected by her husband and the husband was promiscuous then, it seems on the basis of this historical consideration, we are justified to give the medicine to the woman since she is a victim and, in some important sense, it was not her own doing that led to her infection. Here, all things being equal, we are justified to appeal to the past actions and decisions to discriminate in terms of distributing some goods. How people have behaved in the past should affect how we distribute scarce medication, particularly in conditions of scarcity.

It is crucial to note that these two examples appear to be strongly pointing to the direction that historical considerations ought to matter in moral thinking. In other words, here we get the sense that some duties, responsibilities or even rights emerge because of this backward-looking facet of morality as roughly represented by the two examples above. We can, on the basis of this prima facie evidence, set our faces against any moral theory that does not have this backward-looking facet in its decision making. ${ }^{8}$ It is this backward-looking facet that features essentially in rectification justice.

Rectification justice is an attempt to correct historical violations involved in unjust acquisitions and transfers. But this kind of correction anticipated by rectification justice would not make sense if the past and its correction are not important part of moral theorisation. In other words, if rectification justice is true, it implies that we have a duty to be concerned about the past to the point that it recommends some remedy. In what follows, below, I unfold how the past is an important facet of this notion of personhood.

To judge some person to be a person is to evaluate them to be truly leading a life befitting a human being. In the African tradition, it is a crucial consideration to achieve the status of being a moral exemplar, and it is no small matter to fail in this regard (Wiredu 1992, 199; 2009, 14). Wiredu (1992, 200-201) even goes to the point of claiming that this project of attaining personhood is the highest goal of life in African traditional thought. To make the judgement that some human being has either attained personhood or not is to be necessarily involved in a moral evaluation that cannot be divorced from the history of the agent under moral scrutiny. In other words, to judge some human being as a person is tantamount to making a moral evaluation about the agent's conduct over time.

To attain moral perfection one has to live a particular kind of a life and that life, in turn, must produce a particular kind of character. Menkiti $(2004,326)$ speaks of human life as imagined in terms of a 'journey of the individual toward personhood'. The one who makes the judgement about one's status then relies on the record of the agent's life to arrive at the decision that she is a person. In other words, the one making the judgement 
must be aware of the agent's moral journey and how she conducted herself in this moral journey. The issue here is not whether people (those making the judgement) have the correct or incorrect records of history; rather, the issue is that personhood necessarily involves the past and the evaluation of how one conducted herself in it. Therefore, to judge one to be a person is to make a moral judgement about one's past conduct and to validate it as morally acceptable. So, the idea of personhood is a past sensitive and tracking moral notion. Central to this kind of historical analysis of the agent's performance is the assumption that she is a moral agent and one can, therefore, be taken to be morally responsible. This kind of moral evaluation will also look into how she has conducted and responded to social relationships, wherein she was challenged to be better, enabled by the community to achieve her goal and to live harmoniously with others.

In the light of the above, we can safely submit that the idea of personhood imagines a backward-looking moral orientation. The fact that the idea of personhood entails a backward-looking moral orientation or, more appositely, one that takes seriously considerations of the past in its moral reckoning, should come as no surprise. It is also strongly hinted by the high regard African people usually attach to old age (Wiredu 1996; Bell and Metz 2011). The assumption here is that the longer one lives on earth the wiser she becomes. Menkiti (2004, 325, emphasis mine) captures this insight thus: 'The thinking here is that in the normal process of growth and maturation, the heart does grow increasingly wiser, morally speaking. But it all takes time, and there are no short cuts ... '. Furthermore, Menkiti also notes:

The reason for this is that morality and the maturation of the human person are so intimately bound up that a still evolving specimen of the person, lacking a full record in the area of lived experience, would be hard-pressed to present the sort of personal history needed for an elevation into the status of a moral exemplar (325-326).

So, the idea is that the more/longer one lives, she is presented with many opportunities to learn many lessons for her heart to be pure and her mind to be wiser and so grow to become one characterised by moral excellence. ${ }^{9}$ These many opportunities also equally present many temptations for an agent to fail. But, those agents that succeed receive the honour and respect they deserve; that of personhood. Thus, the past is a crucial facet of the ethical system embodied by the idea of personhood that highly prizes every human being for their capacity for moral agency and shows great respect for those moral agents who uses their moral agency to develop moral virtue. Below, I proceed to articulate how this idea of personhood requires particular goods for it to be possible.

\section{Personhood and historical conditions}

Related to this important facet of the past tracking nature of the judgement regarding the quality or defective nature of one's deportment is what I referred to above as socio-historical conditions. By this, I mean specifically, that there are particular conditions/goods that are necessary or even required for an agent to be able to self-realise. In other words, it would be unjust and unreasonable for one to expect human beings to self-realise under social circumstances that render such a goal impossible. To talk even of the possibility of personhood or to even assume the role of evaluating human conduct with the aim of making the judgement regarding the quality of their conduct implies the existence 
of a particular set of conditions that render this judgement reasonable in the first place. I think this submission is vital and worth taking seriously and I am convinced it is entailed by the idea of personhood.

It is crucial to note that central to the concept of personhood is the idea that a just society is one that is conducive for one and all to exercise their humanity so as to realise its true potential, to live a genuine or even a full human life. In other words, it will be irrational for one to expect a human being to attain personhood in an environment that is unconducive for self-perfection like when one has been dispossessed of the material goods that make life possible; when one's culture that buttresses the confidence to be a self with a sense of one's history and destiny is questioned and systematically denied; and when one is denied the dignity that naturally belong to her merely because she is human (Praeg 2014).

So, the political dimensions of the idea of personhood are that there are conditions that are absolutely necessary for one to be able to lead a morally genuine life. Here, what is imagined is the relationship between the kind of a thing a human being is and the kinds of goods required for personhood to be possible. On the one hand, a human being is thought to be special because she has the capacity for virtue. This idea is succinctly captured by Gyekye $(1992,110)$ in this manner: 'every individual is capable of becoming a person inasmuch as he has capacity for virtue-for performing morally right actions - and should be treated (at least potentially) as a morally responsible agent'.

Fundamental to note in Gyekye's thinking, is the idea that every human being has the ontological equipment that specifies them as equal to every other human being and as moral agents like any other human being irrespective of their class or race. This idea that human beings have the capacity for virtue specifies the intrinsic features that render human beings as superlatively valuable or as bearers of dignity (Darwall 1977). This talk of the human capacity for virtue captures the facet of human nature around which the entire political system of Afro-communitarianism revolves, which specifies in virtue of what human beings are equal and informs our moral belief on personhood as a proper moral ideal for human beings. In Gyekye's thinking, what makes human beings special, if we take the idea of personhood qua character perfection seriously, it is their 'innate capacity for virtue, for performing morally right actions and therefore should be treated as a morally responsible' (Gyekye 1992, 110). A human being is morally special, thus deserving moral recognition, because they have the capacity for virtue. The implication of understanding human nature in this manner implies that we require a political system that respects this human capacity for virtue. The aim of morality and politics is to organise society in ways that allows the human being to be able to realise this capacity that is definitive of their humanity and its ideals.

However, it is not enough for us to recognise that human nature is special, because it has this capacity for virtue; more is required for us to have a robust moral-political system. The kind of a thing a human being is - one with the capacity for virtue - further requires certain goods which are conducive for her to function in the world. If a human being is a particular sort of a thing, with particular kinds of capacities, it should follow that she requires certain enabling conditions and goods to be able to self-realise. Generally, these conditions and goods in Afro-communitarian thought are captured in terms of the 'common good' (Gyekye 1992, 2004; Wiredu 1992). The idea of the common good 
is usually captured by appeal to the Siamese crocodile with two heads and one stomach. Gyekye (2010) comments thus on this moral imagery:

The part of the motif relevant to moral thought is the single stomach... The common stomach ... indicates that at least the basic interests of all the members of the community are identical. It can therefore be interpreted to be symbolizing ... the good of all the individuals within a society.

The idea of the common good is predicated on the idea that humanity is a property shared commonly by all human beings. This idea of the common good presupposes that there are certain basic needs/goods that are necessary for a human life to be possible (Gyekye 2004). This idea of the common good insists that there are core interests whose fulfilment is a basic requirement of each and every human being, otherwise, life would be handicapped or unfortunate. It is for this reason that in another place Gyekye $(1997,67)$ refers to them as 'human goods'. These basic goods cover political institutions and other necessary social facets required for a human life to be possible. I call this the common good condition. This condition is crucial because it is reflective of the communitarian orientation of African ethics rather than an individualistic orientation, which will emphasise individual human differences and rights (Gyekye 2004).

What is beginning to emerge is that the idea of personhood is built on a particular moral-political philosophy. Firstly, this system requires that we understand the kind of a thing a human being is (one characterised by capacities for virtue). Secondly, it also expects to understand the history (the context within which the agent exercises her humanity and where the judgement regarding her performance is made) and the historical conditions (to consider whether the agent has access to basic human goods necessary for her to develop her humanity - the common good). Without these conditions, human life is crippled and rendered almost impossible. The concept of personhood as an achievement depends on these facets, which account for a just society. Therefore, it is safe to submit: a just society is one that respects human beings in the light of their capacity for virtue and one that maximises social, political and economic resources for one to be able to self-realise. I turn now to consider the question of rectification justice.

\section{Personhood and rectification justice}

The process of colonisation and apartheid (in the case of South Africa) disturbed both of these crucial conditions for personhood to be possible. Central to these historical processes was (1) the denial of the humanity of African people (capacity for virtue) and (2) the common goods necessary for them to live a robust human life and self-realise were effectively removed. Colonisation halted the possibility and prospects of a black humanity both as individuals and a collective to develop. The systematic denial of the humanity of blacks and the almost complete removal of necessary goods to make human life possible marks a great injustice against the humanity of black people and its possibilities.

The great injustice committed against African people can best be understood in terms of being plucked out of the domain of morality. To deny human beings, their humanity and the goods necessary for them to develop as human beings is tantamount to rendering them 'amoral' in two crucial ways. Firstly, you treat them as things, i.e. as outside of the scope of moral-political concern. As they are outside of the moral community; they are 
either transferred to the inferior animal kingdom or they are treated as moving things. Human beings reduced to this level of existence cannot be wronged, made worse off, and by treating them anyhow one is not doing something wrong, flouting some moral principle (Metz 2012b). Put simply, they are put outside of the moral community, and, as such, they are outside of the protection offered by morality. ${ }^{10}$ The second sense of their 'amoral' status involves the fact they are put in an existence where they are beyond the reach of the moral judgement where they can either be considered as persons or not. In other words, not only have they lost all considerations of moral status that would naturally demand that they are equal to every other human being; but they have lost the opportunity for them to be directors of their own humanity to lead it to self-realise or make the best of it. The moral goal of self-realisation is no longer a consideration available to them, because the common good requirement was seriously undermined by the historical processes of colonisation. African people in a state of denied humanity and removal of social arrangements necessary for humanity to be possible are subjected to an engineered perpetual state of moral bad 'luck'.

Thus, rectification justice matters on the moral idea of personhood because it should look into reversing the disturbance of these two conditions - human equality/dignity and common good - necessary for human life to be possible. The unjust acquisitions and transfers must be revisited for the sake of normalising conditions for humanity to be possible for African people. Hence, there must be a deep investigation into the past so that we can correct or even remove all socio-political technologies put in place to ensure the extirpation of conditions that continue to make human life impossible for African peoples. The greatest challenge and goal of rectification justice is to re-insert African people into the realm of morality, where they can freely and fully exercise their humanity and be put in a position where they can either be criticised or praised for making something of their humanity. So, central to the idea of personhood with regards to rectification justice is a call for correcting the past to create a social-world where morality is a possibility for African peoples.

This normalising of conditions as the necessary facet of rectification justice involves essentially re-ordering society such that it enables all human beings to be able to function, or to self-realise. In other words, according to personhood, the aim of rectification justice is not necessarily to revert to the original situation. ${ }^{11}$ The aim, rather, of justice is captured by these two facets of personhood: (1) to create a world where the humanity of all, the oppressed and oppressor, is equally recognised and respected for its capacity for virtue and, (2) to create conditions where all the basket of goods, be they social, political and economic arrangements, are available to each and all so that they are in a position to self-realise. The goal of this moral-political system is the attainment of perfection.

Injustices of the past had put African peoples, in particular, in a position where they may not be able to live according to the ideals associated with what is ideal for their humanity personhood. The aim of rectification justice, then, is to rectify a society that undermines human capacities for virtue and to create one that allows human beings, if they so will, to pursue ideals associated with their humanity. Priority will be placed on African peoples as they were victims of injustices, but the ultimate goal is the equalisation of the moral platform for all to be able to self-realise. ${ }^{12}$

To give concreteness to this vision of rectification justice, I take as an example, the difficult question of land. Central to keep in mind according to personhood is that it operates 
on a completely different moral logic when it comes to questions of land ownership. In the discourse of personhood, the land is not imagined within the Western strictures of private property. In the first instance, the land is generally owned in common. Metz $(2007,325)$ is correct to observe that

In many traditional African societies land is ultimately owned in common and it is held that labour should be undertaken for the sake of the community, neither in order to make a profit in light of demand nor simply to care for one's immediate family.

The land question is a complex one, and I will not attempt to settle it in few sentences. But, with regards to personhood, one central contribution this discourse can make is to rethink the question in ways that are beneficial to all. As such, personhood, in the first instance, will seriously challenge the dominant logic of thinking of our relation to land as a private property, particularly where it has implications as a resource that can benefit all. Secondly, personhood will insist on the distribution of land in ways that will optimise its value for the community as a whole. In other words, in this interpretation, rectification justice will approach the land question, not with an eye single to returning land to its original historical patterns of ownership as a priority. Rather, the solution that emerges will involve distributing and utilising it for the benefit of all. To talk of 'benefit', in this instance, includes using the land for settlement, agricultural and cultural purposes - the grounding moral motif to this approach to land and our relationship to it is that it is part of the common good, which should be used to enable individuals to self-realise.

As such, the greatest challenge and goal posed by rectification justice construed in the light of the Afro-communitarian moral notion of personhood requires re-insertion of African people into the realm of morality, where they can freely and fully exercise their humanity and be put in a place where they can either be criticised or be praised for making something of their humanity. So, central to the idea of personhood with regards to rectification justice is a call for correcting the past to create a social-world where morality is a possibility, not just for African people, but for all human beings in societies that have an ugly history of injustices. We cannot talk of a brotherhood of all humanity and shared humanity unless we imagine a world where we recognise the humanity of all for its capacity for virtue and we equally provide the common goods for humanity to able to flourish (Praeg 2014).

\section{Conclusion}

In this article, I revisited Afro-communitarianism in terms of the notion of personhood to shed light on how it will approach historical injustices. Two central facets of personhood were brought to our attention: (1) what renders human beings morally special - their capacity for virtue and (2) the set of goods necessary for a human being to be able to function. I argued that these two facets are at the heart of the moral-political scheme of Afrocommunitarianism. A just society is one that respects human beings in virtue of their capacity for virtue and one that provides goods necessary for them to be able to lead a robust life, one that can self-realise. The aim of rectification justice is ensuring that these two conditions prevail for all humanity to be able to self-realise. The aim of rectification justice is to create those conditions necessary for (all) human beings to be able to selfrealise. In a very rough way, I suggested that a rectificative approach to the question of 
land requires a re-distribution of it that ultimately optimises conditions for the self-realisation of all humanity.

\section{Notes}

1. I am using Nozick's entitlement conception of justice because I am ultimately interested in addressing historical injustices. Surely, there are many ways to address historical injustices, I rely on the idea of 'rectification justice' for heuristical purposes to give us some sense of thinking about how to address historical injustices. As such, I am not committed to this idea for its own sake or even the entire political edifice within which Nozick imagines it. I think it is one useful way, heuristically, to think about past injustices in light of an influential African ethical concept of personhood.

2. Jason Van Niekerk's (2013) doctoral thesis does a good job of defending this position in African ethics.

3. I am aware that Thad Metz $(2011,2013)$ does touch on addressing historical injustices and he insists that past injustices ought to be a feature of a robust moral theory. It is important, however, to note that in these articles Metz is not directly discussing the question of addressing historical injustices per se, but is ultimately showcasing that his theory does a better job than that of Wiredu, because it has the corpus to include past considerations in its moral purview. My aim just is to reveal the moral resources inherent in this idea of personhood to address historical injustices. Further, Metz takes a rights-based approach to address historical injustices. Elsewhere, I have argued that rights are incompatible with much of African moral-political thinking, particularly the moral logic inherent in the idea of personhood (Molefe 2017a). Elsewhere, I also argued that the theory that Metz relies on to address historical injustices is implausible, and, as such, if I am correct, it should not be taken seriously (Molefe 2017b).

4. Stephen Darwall's (1977) article 'Two Kinds of Respect' anticipates the distinction between these patient-centred and agent-centred notions of personhood. For a brilliant distinction between these two concepts of personhood, see Behrens (2013) article 'Two Normative Conceptions of Personhood'.

5. A cautious reader will note, however, that the entire article tethers the patient-centred and the agent-centred notions of personhood in its approach to questions of justice.

6. See Gyekye's (1992) analysis of Afro-communitarianism.

7. I adopted this example from Metz (2013).

8. Think of act-utilitarianism, for example: the right action is defined as one that maximizes certain outcomes in the future (MacNaughton and Rawling, 2006). If I make a promise or even take a loan, when the time to fulfil my promise or to pay may dues, the most important consideration is not the mere fact that I promised (backward-looking moral logic) but rather what course of action(s) will maximise the good (forward-looking moral logic).

9. I will not here burden myself with the question of whether this necessarily implies that children are less moral than adults or they are merely untested or they are amoral. I would favour a position that considers them relative to their experience. But, I need not have answers to this question since it does affect my conclusions.

10. It is crucial that the social-political arrangements that are put in place ensure their amorality.

11. The reason for this is that the aim is a just society, and not correcting history for the sake of correcting history. Also, the reason is that the oppressor and the oppressed are both human; and, as such, both require conditions conducive for human beings to self-realize. The goal is putting in place an order conducive for all humanity to flourish.

12. I am committed to egalitarianism.

\section{Disclosure statement}

No potential conflict of interest was reported by the author. 


\section{References}

Behrens, K. 2013. "Two Normative Conceptions of "Personhood"." Quest (grand Rapids, Mich) 25: 103119.

Bell, D., and T. Metz. 2011. "Confucianism and Ubuntu: Reflections on a Dialogue between Chinese and African Traditions." Journal of Chinese Philosophy 38: 78-95.

Bujo, B. 1997. The Ethical Dimension of Community. Nairobi: Paulines Publications Africa.

Bujo, B. 2001. Foundations of an African Ethic: Beyond the Universal Claims of Western Morality. New York: The Crossroad Publishing Company.

Darwall, S. 1977. "Two Kinds of Respect." Ethics 88: 36-49.

Dworkin, R. 1983. "Comment on Narveson: in Defense of Equality." Social Philosophy and Policy 1: 2440.

Gyekye, K. 1992. "Person and Community in African Thought." In Person and Community: Ghanaian Philosophical Studies, 1, edited by K. Gyekye, and K. Wiredu, 101-122. Washington, DC: Council for Research in Values and Philosophy.

Gyekye, K. 1995. An Essay on African Philosophical Thought: The Akan Conceptual Scheme. Philadelphia: Temple University Press.

Gyekye, K. 1997. Tradition and Modernity. New York: Oxford University Press.

Gyekye, K. 2004. Beyond Cultures: Perceiving a Common Humanity, Ghanaian Philosophical Studies. Accra: The Ghana Academy of Arts and Sciences.

Gyekye, K. 2010. "African Ethics." In The Stanford Encyclopaedia of Philosophy, edited by E. N. Zalta. Accessed 16 January 2013. http://plato.stanford.edu/archives/fall2011/entries/african-ethics.

Ikuenobe, P. 2006. "The Idea of Personhood in Chinua Achebe's Things Fall Apart." Philosophia Africana 9: 117-131.

Kaphagawani, D. 2004. "African Conceptions of a Person: A Critical Survey." In Companion to African Philosophy, edited by K. Wiredu, 332-442. Oxford: Blackwell Publishing.

Kymlicka, W. 1990. Contemporary Political Philosophy: An Introduction. Oxford: Clarendon Press.

Lutz, D. 2009. "African Ubuntu Philosophy and Global Management." Journal of Business Ethics 84: 313-328.

MacNaughton, D., and P. Rawling. 2006. "Deontology." In Oxford Handbook of Ethical Theory, edited by D. Copp, 425-458. Oxford: Oxford Press.

Mbiti, John. 1969. African Religions and Philosophy. New York: Doubleday.

Menkiti, I. 1984. "Person and Community in African Traditional Thought." In African Philosophy: An Introduction, edited by R. A. Wright, 171-181. Lanham: University Press of America.

Menkiti, I. 2004. "On the Normative Conception of a Person." In Companion to African Philosophy, edited by K. Wiredu, 324-331. Oxford: Blackwell Publishing.

Metz, T. 2007. "Ubuntu as a Moral Theory: Reply to Four Critics." South African Journal of Philosophy 26: $369-387$.

Metz, T. 2009. "Human Dignity, Capital Punishment and an African Moral Theory: Toward a New Philosophy of Human Rights." Journal of Human Rights 9: 81-99.

Metz, T. 2011. "Ubuntu as a Moral Theory and Human Rights in South Africa." African Human Rights Journal 11: 532-559.

Metz, T. 2012a. "Ethics in Africa and in Aristotle: Some Points of Contrast." Phronimon 13: 99-117.

Metz, T. 2012b. "An African Theory of Moral Status: A Relational Alternative to Individualism and Holism." Ethical Theory and Moral Practice 15: 387-402.

Metz, T. 2013. "Two Conceptions of African Ethics in the Work of D.A. Masolo." Quest (grand Rapids, Mich ) 25: 141-161.

Mokgoro, Y. 1998. "Ubuntu and the Law in South Africa." Potchefstroom Electronic Law Journal 1: 111.

Molefe, M. 2016. "Revisiting the Debate between Gyekye-Menkiti: Who is a Radical Communitarian." Theoria 63: 37-54.

Molefe, M. 2017a. "Personhood and Rights in an African Tradition." South African Journal of Political Studies. doi:10.1080/02589346.2017.1339176. 
Molefe, M. 2017b. "Relational Ethics and Partiality: A Critique of Thad Metz's 'Towards an African Moral Theory'." Theoria 64: 53-76.

Munyaka, M., and M. Motlhabi. 2009. "Ubuntu and its Socio-moral Significance." In African Ethics: An Anthology of Comparative and Applied Ethics, Vol. 69, edited by F. M. Murove, 71-72.

Nozick, R. 2002. "A Libertarian Theory of Justice." In Political Philosophy: Classic and Contemporary Readings, edited by L. Pojman, 256-270. New York: McGraw Hill.

Oyowe, A. 2014. "An African Conception of Human Rights? Comments on the Challenges of Relativism." Human Rights Review 15: 329-347.

Praeg, L. 2014. A Report on Ubuntu. Pietermaritzburg: University of KwaZulu of Press.

Rachels, J., and S. Rachels. 2015. The Elements of Moral Philosophy. Boston: McGraw Hill.

Shutte, A. 2001. Ubuntu: An Ethic for a New South Africa. Pietermaritzburg: Cluster Publications.

Toscano, M. 2011. "Human Dignity as High Moral Status." The Ethics Forum 6: 4-25.

Tshivhase, M. 2013. "Personhood: Social Approval or a Unique Identity?" Quest: An African Journal of Philosophy 25: 119-140.

Tutu, D. 1999. No Future Without Forgiveness. New York: Random House.

Van Niekerk, J. 2013. Ubuntu and Moral Theory. Johannesburg: University of Witwatersrand.

Wiredu, K. 1992. "Moral Foundations of an African Culture." In Person and Community: Ghanaian Philosophical Studies, 1, edited by K. Wiredu, and K. Gyekye, 192-206. Washington, DC: The Council for Research in Values and Philosophy.

Wiredu, K. 1996. Cultural Universals and Particulars: An African Perspective. Indianapolis: Indiana University Press.

Wiredu, K. 2008. "Social Philosophy in Postcolonial Africa: Some Preliminaries Concerning Communalism and Communitarianism." South African Journal of Philosophy 27: 332-339.

Wiredu, K. 2009. "An Oral Philosophy of Personhood: Comments on Philosophy and Orality." Research in African Literatures 40: 8-18. 